\begin{tabular}{|c|c|c|}
\hline 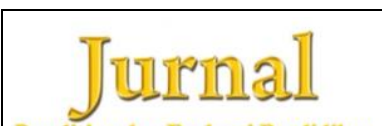 & $\begin{array}{c}\text { Jurnal Penelitian dan Evaluasi Pendidikan } \\
\text { Volume 23, No 1, June } 2019 \text { (1-11) }\end{array}$ & \\
\hline Itian dan Evaluasi Pendidikan & Online: http://journal.uny.ac.id/index.php/jpep & \\
\hline
\end{tabular}

\title{
DEVELOPMENT OF SELF-RATING SCALE INSTRUMENT OF SELF-DIRECTED LEARNING SKILLS FOR HIGH SCHOOL STUDENTS
}

\author{
Intan Febry Sulasiwi \\ Graduate Program, Universitas Negeri Malang \\ Supriyono Koes Handayanto \\ Department of Physics FMIPA, Universitas Negeri Malang \\ Wartono \\ Department of Physics FMIPA, Universitas Negeri Malang
}

\begin{abstract}
This study aims to develop a valid and reliable self-rating scale instrument for measuring SelfDirected Learning (SDL) skills. This DDI study follows the steps of Hinkin's development (1995) which consists of five stages: creating an item pool, expert conclusion, implementation, confirmatory factor analysis, and reliability analysis. The self-rating scale developed in this study consisted of sixty statements accompanied by a 1-5 Likert scale. Based on the factors analysis, 16 items were still in the draft and 44 items were declared valid and reliable. Five factors that are determined are: awareness ( 8 items, $\alpha=0.717$ ), learning strategies ( 9 items, $\alpha=0.806$ ), and learning activities (7 items, $\alpha=0.777$ ), evaluation ( 8 items, $\alpha=0.790$ ), and interpersonal skills (12 items, $\alpha=0.907)$. The reliability coefficient (Cronbach Alpha) of the self-rating scale is $\alpha=$ 0.933 , with the required reliability criteria is 0.5 . On a scale conversion of $1-100$, the student's highest score of SDL skills is 93, and the lowest score SDL skills are 31 (SD =20.334).
\end{abstract}

Keywords: self-rating scale, self-directed learning skills, high school students

Permalink/DOI: http://dx.doi.org/10.21831/

Contact Supriyono Koes Handayanto

supriyono.koeshandayanto.fmipa@um.ac.id

- Department of Physics FMIP A, State University of Malang

Jalan Semarang 5, Sumbersari, Kec. Lowokwaru, Kota Malang, Jawa Timur 65145, Indonesia 


\section{Introduction}

Skills for self-directed learning among students and their role in improving lifelong learning skills have been emphasized lately (Taqipour, Abbasi, Naeimi, Ganguly, \& Miandashti, 2016). With the development of information and technology today, students need to be equipped with the skills to navigate unexpected challenges in the future such as those contained in self-directed learning skills (SDLS) (Scott, 2015). Self-directed learning (SDL) skills allow students to know what they are learning about their learning pathways and freely choose how they will learn (Acar, Kara, \& Taşkin Ekici, 2016). Thus, the SDL skills are key factors that affect the ability of lifelong learning (Shen, Chen, \& Hu, 2014). Additionally, SDLS is one factor that contributes to higher achievement in science (Kan'an \& Osman, 2015).

Mastery of SDLS allows independently student-centered learning to occur more optimally. This is in accordance with the definition of SDLS offered by Knowles (1975), namely description of process in which individuals take the initiative, with or without the assistance of others, in diagnosing their learning needs, formulating learning goals, identifying human resources and learning materials, choosing and implementing appropriate strategies, and evaluating learning outcomes. Merriam \& Caffarella (1999) (in Huang, 2008) added the definition of SDL as a process where a person can take the initiative to plan, implement, and evaluate his learning process as a "personal attribute" which includes initiative, ability, and willingness of students to control essential selfdirected learning process. This shows that SDL skills have a shared commitment to changes in position and role of students where students hold more significant control over themselves in terms of conceptualization, design, implementation, and evaluation of learning and the application of ways to use learning resources for further learning.

Seeing the importance of SDL skills, SDLS research on physics is still limited. One of the studies that have been done is to find the relationship between problem-based learning and SDLS to the problem of global warming and power plants (Malan, Ndlovu, \& Engelbrecht, 2014). Besides, previous research carried out was limited to straight motion and work and energy (Yasa, 2014). While research related to the development of a self-rating scale to measure the SDL Skills is still not done.

The most widely used instrument in educational research to measure SDL skills is the Self-Directed Learning Readiness Scale (SDLRS) developed by Guglielmino (1977). The problem with this instrument is effectiveness and practicality. Field (1991) examined the relationship among item scales, factors and SDLRS total scores of respondents. Some items do not reach 0.35 on one of eight factors. Correlation between items and a total score of SDLRS is 0.30 . These results indicate that the scale does not measure SDL skills. Based on the problems with the validity test of the instrument, Field (1991) suggested stopping using this instrument. Bonham (1991) also reported concerns about the validity of SDLR constructs by questioning the meaning of low scores. It was concluded that low scores did not measure low SDL readiness, thus construct validity is questionable for low SDLRS values. Although measuring devices such as the Guglielmino SDLRS have been developed, this self-rating scale is not available and is subject to fees for its use.

Gündüz \& Selfi (2016) developed a Self-Directed Learning Implementation Skills Scale that is intended for elementary school students. In addition, most of the instruments developed are specifically for the world of medical or medical education such as the Self-Directed Learning Readiness Scale (SDLRS) developed by Guglielmino (1977), Self-Rating Scale of Self-Directed Learning (SRSSDL) developed by Williamson (2007), The Self-Rating Scale SelfDirected Learning Italian version (SRSSDLIta) developed by Cadorin, Ghezzi, Camillo, \& Palese (2017), Self-Directed Learning Instrument (SDLI) developed by Shen et al. (2014) and Self-Directed Learning Readiness 
Scale developed by Williams \& Brown (2013).

Related to Science education, a SelfDirected Learning Skills Scale has been developed for students of prospective science teachers by Acar et al. (2015). Whereas for research in physics education as done by Yasa (2014) adapted the Williamson instrument (2007). Related to this, the development of a self-rating scale for self-directed learning skills for high school students especially those who are taking physics learning refers to the Self-Rating Scale of SelfDirected Learning (SRSSDL) developed by Williamson (2007). SRSSDL of sixty statements accompanied by a Likert (1932) scale of 1-5. The sixty statements are evenly distributed on five factors. These five factors are awareness, learning strategies, learning activities, evaluation, and interpersonal skills.

The purpose of this study is to develop an instrument self-rating scale of self-directed learning skills for high school students, especially MIPA majors. Another goal is to find out the validity and reliability of selfrating scales for advanced self-directed learning skills. Besides that as a result of the implementation phase, this study also aims to determine the Self-Directed Learning skills of high school students in class X, XI, and XII MIPA

\section{Research Method}

The DDI (Design, Development, and Implementation) research method was implemented and adapted from the development steps of Hinkin (1995). There are five primary stages in developing the Hinkin scale, namely: creating an item pool, expert conclusion, application, factor analysis, and reliability analysis. This research followed all the steps needed to develop the scale as stated by Hinkin.

The first step is to create an item group. At this stage, an assessment of the self-rating scale for existing self-directed learning skills was carried out. The most widely used instrument in educational research to measure SDL skills is the SelfDirected Learning Readiness Scale (SDLRS) developed by Guglielmino (1977). The problem with this instrument is the validity and reliability and the cost of the use of this instrument.

In physics education research as done by Yasa (2014) adapted the Williamson instrument (2007). Related to this, the development of the self-rating scale of self-directed learning skills for high school students especially those who are taking physics learning refers to the Self-Rating Scale of SelfDirected Learning (SRSSDL) developed by Williamson (2007).

Based on the literature, 60 items will be used. The first thing to do is to translate the language, which is to translate from English to Indonesian. Then it provides remarks for some terms that are not familiar to high school students. Also, this statement is intended to equalize student perceptions regarding the statements on each item so that it is more focused on a particular purpose. In each item, it accompanied by a Likert rating scale in the form of 1-5. In the end, adjustments are made for instructions and student data.

The second stage is an expert conclusion. At this stage language, construct, and content validation is done. Language validation to assess the structure of the sentence and the meaning contained in it as well as the ease of students in accessing the meanings contained in the items under physics. Construct validation to assess the suitability of the item with its construct and the completeness of the self-rating scale instrument with scoring guidelines. Content validation is done to assess the statement on the item so that it corresponds to learning activities on physics. Validation was carried out by two expert lecturers. The results of this validation need to be revised on 1 item. The self-rating scale instrument in this stage has been revised and still consists of 60 items.

The third stage is implementation. According to the literature, the sample size is an essential problem in obtaining valid results from factor analysis. Kline (1994) (in Gündüz \& Selfi, 2016) states that 200 partisans are sufficient to identify the decisive 
factors in factor analysis. Thus, at this stage, the final form of the self-rating scale draft was given to convenience samples of 216 high school students majoring in MIPA of classes X, XI, and XII. The participants' demographics in detail can be seen in Table 1.

Table 1. Demographics of Participants

\begin{tabular}{|c|c|c|c|}
\hline \multicolumn{2}{|c|}{ Demographics of Participants } & \multirow{2}{*}{$\begin{array}{c}\begin{array}{c}\text { Fre- } \\
\text { quency }\end{array} \\
73\end{array}$} & \multirow{2}{*}{$\begin{array}{c}\% \\
33.8\end{array}$} \\
\hline Gender & Man & & \\
\hline Gender & Women & 143 & 66.2 \\
\hline \multirow{3}{*}{$\begin{array}{l}\text { Class } \\
\text { Level }\end{array}$} & Class X & 121 & 56.0 \\
\hline & Class XI & 77 & 35.7 \\
\hline & Class XII & 18 & 8.3 \\
\hline \multirow{5}{*}{$\begin{array}{c}\text { Age } \\
\text { Range }\end{array}$} & 14 years & 3 & 1.4 \\
\hline & 15 years & 52 & 24.1 \\
\hline & 16 years & 106 & 49.1 \\
\hline & 17 years & 49 & 22.7 \\
\hline & 18 years & 6 & 2.7 \\
\hline \multirow{2}{*}{ School } & SMAK Yos Sudarso & 54 & 25.0 \\
\hline & SMAN 1 Talun & 162 & 75.0 \\
\hline
\end{tabular}

The fourth stage is factor analysis. Factor analysis was performed with SPSS 17.0. This analysis is done to determine the construct validity of the self-rating scale. The fifth stage is the analysis of reliability. Reliability analysis was carried out with SPSS 17.0.

\section{Findings and Discussion}

Unidimensionality item

The unidimensional scale is one, where each item measures the same basic concept, in this case, the SDL skill. To test unidimensionality, which is whether the response to a particular item reflects a response to another item, the item-total correlation coefficient is done and the results obtained as shown in Table 2. The higher the coefficient for each item the more the item is included in the scale. Generally, the coefficient of less than 0.30 indicates that the item should be removed from the scale. Five of the sixty items produce coefficients less than 0.30 and are therefore excluded from the scale. The five deleted scales are 1.3, 1.9, 1.10, 2.2, and 3.12.
Factor Analysis of Awareness Indicators

The first condition for analyzing a factor is if the KMO (Kaiser Meyer Olkin) value is high, which is more than 0.5 . The second condition is the value of Approx. Chi-Square on Bartlett's Test for correlation between variables more than 0.5 with Sig. on Bartlett's Test less than 0.05. At SPSS output the awareness indicator shows the KMO value is 0.818 , the value of Approx. Chi-Square on Bartlett's Test is 425.056, and Sig.at Bartlett's Test is 0.000 . Based on the three conditions, it can be said that the variables and samples used to allow further analysis.

Table 2. Statistics of Item-Total Correlations

\begin{tabular}{|c|c|c|c|c|}
\hline Item & Mean & SD & $\begin{array}{l}\text { Corrected } \\
\text { item-total } \\
\text { correlation }\end{array}$ & $\begin{array}{c}\text { Cronbach's } \\
\text { Alpha if } \\
\text { items } \\
\text { deleted }\end{array}$ \\
\hline 1.1 & 3.54 & 0.746 & 0.469 & 0.941 \\
\hline 1.2 & 3.72 & 0.726 & 0.339 & 0.941 \\
\hline 1.3 & 3.86 & 0.859 & 0.270 & 0.942 \\
\hline 1.4 & 3.25 & 0.859 & 0.380 & 0.941 \\
\hline 1.5 & 3.57 & 0.912 & 0.477 & 0.941 \\
\hline 1.6 & 3.70 & 0.871 & 0.428 & 0.941 \\
\hline 1.7 & 3.38 & 0.870 & 0.330 & 0.942 \\
\hline 1.8 & 3.53 & 0.846 & 0.487 & 0.941 \\
\hline 1.9 & 3.97 & 0.940 & 0.292 & 0.942 \\
\hline 1.10 & 3.37 & 0.889 & 0.284 & 0.942 \\
\hline 1.11 & 3.60 & 0.964 & 0.534 & 0.940 \\
\hline 1.12 & 2.93 & 1,030 & 0.334 & 0.942 \\
\hline 2.1 & 3.66 & 0.869 & 0.552 & 0.940 \\
\hline 2.2 & 3.70 & 0.897 & 0.240 & 0.942 \\
\hline 2.3 & 3.15 & 0.869 & 0.357 & 0.941 \\
\hline 2.4 & 4.09 & 0.890 & 0.430 & 0.941 \\
\hline 2.5 & 3.96 & 0.856 & 0.395 & 0.941 \\
\hline 2.6 & 3.63 & 1,070 & 0.421 & 0.941 \\
\hline 2.7 & 3.92 & 0.973 & 0.482 & 0.941 \\
\hline 2.8 & 3.77 & 1,022 & 0.531 & 0.940 \\
\hline 2.9 & 3.33 & 0.872 & 0.489 & 0.941 \\
\hline 2.10 & 3.39 & 0.953 & 0.462 & 0.941 \\
\hline 2.11 & 3.77 & 1,035 & 0.474 & 0.941 \\
\hline 2.12 & 3.50 & 0.935 & 0.509 & 0.941 \\
\hline 3.1 & 3.23 & 0.862 & 0.566 & 0.940 \\
\hline 3.2 & 3.73 & 0.946 & 0.378 & 0.941 \\
\hline 3.3 & 3.22 & 0.937 & 0.574 & 0.940 \\
\hline 3.4 & 3.54 & 0.939 & 0.526 & 0.940 \\
\hline 3.5 & 3.26 & 0.983 & 0.451 & 0.941 \\
\hline 3.6 & 3.29 & 1,066 & 0.491 & 0.941 \\
\hline 3.7 & 3.34 & 0.858 & 0.335 & 0.941 \\
\hline 3.8 & 3.49 & 0.852 & 0.409 & 0.941 \\
\hline 3.9 & 3.28 & 0.914 & 0.511 & 0.941 \\
\hline 3.10 & 3.34 & 0.796 & 0.520 & 0.941 \\
\hline
\end{tabular}




\begin{tabular}{lcccc}
\hline Item & Mean & SD & $\begin{array}{c}\text { Corrected } \\
\text { item-total } \\
\text { correlation }\end{array}$ & $\begin{array}{c}\text { Cronbach's } \\
\text { Alpha if } \\
\text { items } \\
\text { deleted }\end{array}$ \\
\hline 3.11 & 3.76 & 0.794 & 0.395 & 0.941 \\
3.12 & 4.04 & 0.870 & 0.104 & 0.943 \\
4.1 & 3.55 & 0.770 & 0.423 & 0.941 \\
4.2 & 3.56 & 0.861 & 0.417 & 0.941 \\
4.3 & 3.40 & 0.919 & 0.430 & 0.941 \\
4.4 & 3.72 & 0.969 & 0.504 & 0.941 \\
4.5 & 3.95 & 0.755 & 0.415 & 0.941 \\
4.6 & 4.26 & 0.830 & 0.496 & 0.941 \\
4.7 & 4.01 & 0.792 & 0.343 & 0.941 \\
4.8 & 3.44 & 0.828 & 0.483 & 0.941 \\
4.9 & 3.13 & 0.980 & 0.367 & 0.941 \\
4.10 & 3.41 & 0.906 & 0.516 & 0.941 \\
4.11 & 3.35 & 0.902 & 0.617 & 0.940 \\
4.12 & 4.35 & 1,010 & 0.469 & 0.941 \\
5.1 & 3.99 & 0.972 & 0.399 & 0.941 \\
5.2 & 3.64 & 0.888 & 0.583 & 0.940 \\
5.3 & 3.93 & 0.912 & 0.565 & 0.940 \\
5.4 & 3.68 & 0.871 & 0.570 & 0.940 \\
5.5 & 3.98 & 0.937 & 0.452 & 0.941 \\
5.6 & 4.09 & 0.933 & 0.529 & 0.940 \\
5.7 & 3.73 & 0.976 & 0.424 & 0.941 \\
5.8 & 3.62 & 0.908 & 0.609 & 0.940 \\
5.9 & 3.45 & 0.856 & 0.549 & 0.940 \\
5.10 & 3.42 & 0.952 & 0.464 & 0.941 \\
5.11 & 3.65 & 0.922 & 0.574 & 0.940 \\
5.12 & 3.91 & 0.989 & 0.467 & 0.941 \\
\hline & & & & \\
\hline
\end{tabular}

Furthermore, what is seen is the Component Matrix Table. In the Component Matrix Table there should only be one component, but in this case, there are three components. If in the table there are more than one component this indicates that there is an invalid statement. Thus an item reduction is needed. To reduce items can be seen based on the MSA (Measures of Sampling Adequacy) contained in the Anti-Image Matrices Table. The lowest MSA value item must be discarded. The lowest MSA value found in the table is 0.774 for statement 1.9.

Then repeated analysis by removing item 1.9 and still found three components. Then the removal of item 1.10 was carried out, and there were still three components. Followed by deleting item 1.3 and there are still two components. Finally, after deleting item 1.6, one component is obtained in the Component Matrix Table as a factor value of each item. The factor value for each item of awareness indicator after reduction can be seen in Table 3.
Factor Analysis of Learning Strategies Indicators

At the SPSS output, the learning strategy indicator shows the $\mathrm{KMO}$ value is 0.861, the value of Approx. Chi-Square on Bartlett's Test is 433.430, and Sig. Bartlett's Test is 0.000 . Of the three conditions, it can be said that the variables and samples used to allow further analysis. Furthermore, with the same analysis previously items were successively reduced between 2.2, 2.9 and 2.8. The factor value for each item indicator of learning strategy after reduction can be seen in Table 3.

Factor Analysis of Learning Activity Indicators

In the SPSS output, the learning activities indicator shows the KMO value is 0.808, the value of Approx. Chi-Square on Bartlett's Test is 551.069, and Sig.at Bartlett's Test is 0.000 . Of the three conditions, it can be said that the variables and samples used to allow further analysis. Furthermore, with the same analysis as before, items were reduced in succession, including 3.12, 3.2, 3.7, 3.9 and 3.8. The factor value for each item in the learning activity after reduction can be seen in Table 3 .

\section{Factor Analysis of Evaluation Indicators}

At the SPSS output, the indicator of learning activities shows the KMO value is 0.846, the value of Approx. Chi-Square on Bartlett's Test is 693.458, and Sig. Bartlett's Test is 0.000 . Of the three conditions, it can be said that the variables and samples used to allow further analysis. Furthermore, with the same analysis as before, item reduction was carried out in succession including 4.12, 4.7, 4.3, and 4.2. Factor value for each item of evaluation indicator after the reduction can be seen in Table 3 .

Factor Analysis of Interpersonal Capability Indicators

At the SPSS output, the indicator of learning activity shows the value of KMO is 0.926, the value of Approx. Chi-Square on 
Bartlett's Test is 1147.279, and Sig. Bartlett's Test is 0.000 . Of the three conditions, it can be said that the variables and samples used to allow further analysis to be carried out. In the indicator of interpersonal ability is found in one component in the Component Matrix Table, so item reduction does not need to be done. The factor values for each item indicator of interpersonal skills can be seen in Table 3.

Table 3. Results of Analysis After Reduction

\begin{tabular}{|c|c|c|c|c|c|}
\hline \multirow[b]{2}{*}{ Item } & \multicolumn{5}{|c|}{ Results of Factor Analysis After Reduction } \\
\hline & $\begin{array}{l}\text { Aware- } \\
\text { ness }\end{array}$ & $\begin{array}{l}\text { Learning } \\
\text { Strategy }\end{array}$ & $\begin{array}{l}\text { Learning } \\
\text { Activities }\end{array}$ & $\begin{array}{l}\text { Evalu- } \\
\text { ation }\end{array}$ & $\begin{array}{c}\text { Interperson- } \\
\text { al ability }\end{array}$ \\
\hline 1.1 & 0.594 & & & & \\
\hline 1.2 & 0.511 & & & & \\
\hline 1.4 & 0.522 & & & & \\
\hline 1.5 & 0.683 & & & & \\
\hline 1.7 & 0.548 & & & & \\
\hline 1.8 & 0.705 & & & & \\
\hline 1.11 & 0.596 & & & & \\
\hline 1.12 & 0.465 & & & & \\
\hline 2.1 & & 0.559 & & & \\
\hline 2.3 & & 0.520 & & & \\
\hline 2.4 & & 0.698 & & & \\
\hline 2.5 & & 0.662 & & & \\
\hline 2.6 & & 0.655 & & & \\
\hline 2.7 & & 0.572 & & & \\
\hline 2.10 & & 0.660 & & & \\
\hline 2.11 & & 0.744 & & & \\
\hline 2.12 & & 0.553 & & & \\
\hline 3.1 & & & 0.625 & & \\
\hline 3.3 & & & 0.731 & & \\
\hline 3.4 & & & 0.660 & & \\
\hline 3.5 & & & 0.627 & & \\
\hline 3.6 & & & 0.653 & & \\
\hline 3.10 & & & 0.608 & & \\
\hline 3.11 & & & 0.478 & & \\
\hline 4.1 & & & & 0.575 & \\
\hline 4.4 & & & & 0.574 & \\
\hline 4.5 & & & & 0.504 & \\
\hline 4.6 & & & & 0.595 & \\
\hline 4.8 & & & & 0.697 & \\
\hline 4.9 & & & & 0.645 & \\
\hline 4.10 & & & & 0.745 & \\
\hline 4.11 & & & & 0.742 & \\
\hline 5.1 & & & & & 0.675 \\
\hline 5.2 & & & & & 0.749 \\
\hline 5.3 & & & & & 0.772 \\
\hline 5.4 & & & & & 0.694 \\
\hline 5.5 & & & & & 0.715 \\
\hline 5.6 & & & & & 0.747 \\
\hline 5.7 & & & & & 0.674 \\
\hline 5.8 & & & & & 0.776 \\
\hline 5.9 & & & & & 0.656 \\
\hline 5.10 & & & & & 0.572 \\
\hline 5.11 & & & & & 0.733 \\
\hline 5.12 & & & & & 0.682 \\
\hline
\end{tabular}

Table 4 presents sample sizes of central tendency and dispersions for the total scale and subscale. The total score for this sample is not normally distributed as indicated by the Sig. on the Kolmogorov-Smirnov normality test is 0.000 . It can be concluded that the number of scores higher than 150 which is 158.12 , cannot indicate the readiness of students for SDL.

Table 4. Reliability Coefficient After Item Reduction

\begin{tabular}{lcccc}
\hline & $\begin{array}{c}\text { Item } \\
\text { Amount }\end{array}$ & Mean & $\begin{array}{c}\text { Std. } \\
\text { Deviation }\end{array}$ & $\begin{array}{c}\text { Cronbach's } \\
\alpha\end{array}$ \\
\hline $\begin{array}{l}\text { Consciousnes } \\
\text { (Awareness) }\end{array}$ & 8 & 27.51 & 4,031 & 0.717 \\
$\begin{array}{l}\text { Learning } \\
\text { Strategy }\end{array}$ & 9 & 33.08 & 5,360 & 0.806 \\
$\begin{array}{l}\text { Learning } \\
\text { Activities }\end{array}$ & 7 & 23.63 & 4,023 & 0.777 \\
$\begin{array}{l}\text { Evaluation } \\
\text { Interpersonal }\end{array}$ & 8 & 28.81 & 4,433 & 0.790 \\
ability & 12 & 45.08 & 7.819 & 0.907 \\
\hline Total & 44 & 158.12 & 20,334 & 0.933 \\
\hline
\end{tabular}

The internal consistency of each component is estimated using the Cronbach alpha coefficient. The values calculated for each item included: awareness ( 8 items, $\alpha=$ 0.717), learning strategies ( 9 items, $\alpha=$ 0.806), learning activities ( 7 items, $\alpha=$ 0.777 ), evaluation (8 items, $\alpha=0.790$ ), and interpersonal abilities (12 items, $\alpha=0.907$ ). The overall internal reliability coefficient (Cronbach Alpha) of the self-rating scale is $\alpha$ $=0.933$. According to deVaus (Fisher, 2001), a scale with an alpha calculation greater than 0.70 he thinks has an acceptable level of internal consistency (although consistency for other types of scale, such as achievement tests, is generally estimated to be at or above $0.80)$.

The primary objective of this study was to develop a valid and reliable scale to understand self-directed learning skills for high school students who will become lifelong learners both now and in the future. According to the factor analysis carried out, the scale is grouped into five factors that is awareness, learning strategies, learning activities, evaluations, and interpersonal skills. 
The findings indicate that the scale developed has appropriate qualifications to determine students' self-directed learning abilities. The scale can help both students and teachers to understand self-directed learning skills in the five factors, especially high school students.

The developer of the Self-Rating Scale of Self-Directed Learning (SRSSDL), Williamson (2007), states that awareness is the ability to detect learning needs. Acar et al. (2015) in their study confirmed that students who have the skills of self-directed learning have awareness towards their responsibility in learning, acting independently without the help of others, having a high sense of curiosity, enthusiasm, confidence, they have the ability to manage time and make plans to complete the work they have set goals. Furthermore, Taqipour et al. (2016) mentioned that the dimension of consciousness shows that students are aware of their responsibility to learn. This awareness is reflected in the following behaviors, namely students able to identify of their own learning needs, customize their learning goals, can choose the best method of learning for them, balancing learning with their daily activities, updating their learning and independent learning. As mentioned by Istiyani (2009), students' awareness is needed in order to maximize their learning.

The factor of learning strategies state strategies used in a variety of different situations to develop student learning (Williamson, 2007). Seifert (1993) defines learning strategies as mental events carried out by students to achieve some desired goals. Deshler \& Schumaker (1986) reinforces the assertion that the student will become independent learners and players in their learning when they begin to produce their learning strategies that apart from the help of teachers. Students' mastery of learning strategies enables them to successfully analyze and solve the new problems they face both at the academic and non-academic environment. Overall, mastery of the learning strategy has to do with self-directed learning skills because the mastery of learning strategies is not only im- mediate but also generalizes learning strategy skills for different situations and settings from time to time. Things like this are commonly known as a life long learning.

The factor of learning activities covers a range of activities carried out an individual in their study (Williamson, 2007). Learning activities are defined by Eurostat (2006) as an activity of individuals organized with the purpose to improve their knowledge, skills, and competencies. The character of this learning activity is done intentionally for specific purposes. Besides, another important character is a form of organized activity, in self-directed learning skills of learning activities are organized by the students who usually involves the transfer of information in the sense that more general (may be an idea, a message, knowledge, strategy). For less organized activities (in the sense that each student will be different) such as self-directed learning, Eurostat (2006) states that determining whether student activities include learning activities or not learning activities must be decided more careful, this depends on presence or absence of intention to study. This is slightly different from more organized activities which are designed based on the students' desire or effort to learn, which will not change the nature of student activities into non-learning activities.

The ability to effectively evaluate has long been known as a cognitive process and is an essential educational goal (Airasian \& Miranda, 2002; Krathwohl, 2002). The factor of evaluation by Williamson (2007) describes student's ability of learning evaluation in different situations and students get feedback from their learning. If students can evaluate their work, then their learning will not depend entirely on external evaluators (Warren, 2010). Thus students will be able to identify and correct their own mistakes, allowing them to learn better themselves. Such is the hope of mastering skills in self-directed learning.

According to Williamson (2007), the factor of interpersonal ability refers to the communication ability of students with others to expand their learning volume. 
These factors are essential forms of interpersonal interaction (Babonea \& Munteanu, 2012), which can strengthen the bond between students and their colleagues and between students and teachers. Past research on communication in learning has identified several variables of interpersonal positively related to learning. These variables include the relationship or closeness between the teacher and students (Andersen, 1979; Frymier \& Houser, 2000; Hughes, 2012), attractiveness and communication style (Norton \& Pettegrew, 1977), adjustments to the school associated with progress and challenges encountered by students (Hughes, 2012), student motivation and beliefs (Koca, 2016), humor (Wanzer \& Frymier, 1999; Ziyaeemehr \& Kumar, 2014), and caring (Teven \& McCroskey, 1997) contribute to an understanding of student relations in class dynamic. Whereas in science education, a sufficiently emphasized variable has an open mind, that is, with open-minded students can change their beliefs (Burns \& Norris, 2009). As confirmed by Hare \& McLaughlin (1998), even though students have certain beliefs they can still accept rationally.

All of the variables included in the interpersonal skills affect how student learning takes place. For example, when students believe that their colleagues and teachers like and respect them, they will tend to be successful during learning activities (Goodenow, 1993; Ryan, Pintrich, \& Midgley, 2001). In academic settings, interpersonal skills help engagement and student learning (Lindsey \& Rice, 2015). By understanding and managing interpersonal skills, students can manage personal intellectual growth and social growth. Increasing interpersonal skills will help students enrich individual relationships, do better learning activities because they can overcome work or tasks that they have designed better.

\section{Conclusion}

Based on the results of research and data analysis, it is known that, of the sixty self-rating scale items that have been developed, there are forty-four items which fall into the valid category. The forty-four selfrating scale items consist of five indicators and have a Cronbach Alfa reliability level of $\alpha=0.933$. This shows that the forty-four self-rating scale items which are divided into five indicators have high reliability so that it can be used to measure self-directed learning skills for high school students, especially majors in Mathematics and Natural Sciences both class X, class XI, and class XII. The self-rating scale developed to measure selfdirected learning skills with SDL skill indicators in the form of awareness, learning strategies, learning activities, evaluation, and interpersonal skills.

Tests that have been declared valid and reliable are then used to measure selfdirected learning skills. The number of respondents was 216 from two different schools namely SMAN 1 Talun and SMAK Yos Sudarso Kepanjen. The total score for this sample is not normally distributed as indicated by the Sig. on the KolmogorovSmirnov normality test is 0.000 . It can be concluded that the number of scores higher than 150 which is 158.12 cannot indicate the readiness of students for SDL. On a scale conversion of 1-100, the highest SDL student skill score was 93, and the lowest SDL skill score was 31 ( $\mathrm{SD}=20.334)$.

The self-rating scale developed to measure students' self-directed learning can be used as a cost-effective research or educational tool. This self-rating scale will help educators, especially in the MIPA department for all levels in diagnosing student learning needs so that educators can apply teaching strategies that are appropriate to student needs. In connection with this development paucity of research that cannot be indicated the readiness of student's selfdirected learning skills. The suggestion for the next researcher is to conduct case study research related to the students' self-directed learning skills who are studying physics to examine individuals in depth.

\section{References}

Acar, C., Kara, I., \& Taşkin Ekici, F. (2016). Development of self directed learning 
skills scale for pre-service science teachers. International Journal of Assessment Tools in Education, 2(2), 3-13. https://doi.org/10.21449/ijate.23956 2

Airasian, P. W., \& Miranda, H. (2002). The role of assessment in the revised taxonomy. Theory Into Practice, 41(4), 249-254. https://doi.org/10.1207/ s15430421 tip4104_8

Andersen, J. F. (1979). Teacher immediacy as a predictor of teaching effectiveness. Annals of the International Communication Association, 3(1), 543-559. https://doi. org/10.1080/23808985.1979.1192378 2

Babonea, A., \& Munteanu, A. (2012). Towards positive interpersonal relationships in the classroom. In International Conference of Scientific Paper.

Bonham, L. A. (1991). Guglielmino's selfdirected learning readiness scale: what does it measure? Adult Education Quarterly, 41(2), 92-99. https://doi. org/10.1177/0001848191041002003

Burns, D. P., \& Norris, S. P. (2009). Openminded environmental education in the science classroom. Paidousis, 18(1), 35-42.

Cadorin, L., Ghezzi, V., Camillo, M., \& Palese, A. (2017). The self-rating scale of self-directed learning tool: findings from a confirmatory factor analysis. Journal of Nursing Education and Practice, 7(2). https://doi.org/10.5430/jnep.v7 n2p31

Deshler, D. D., \& Schumaker, J. B. (1986). Learning strategies: an instructional alternative for low-achieving Adolescents. Exceptional Children, 52(6), 583-590. https://doi.org/ $10.1177 / 001440298605200611$

Eurostat. (2006). Classification of learning activities-manual. Luxembourg: Office for Official Publications of The European Communities.
Field, L. (1991). Guglielmino's self-directed learning readiness scale: should it continue to be used? Adult Education Quarterly, 41(2), 100-103. https:// doi.org/10.1177/00018481910410020 04

Frymier, A. B., \& Houser, M. L. (2000). The teacher-student relationship as an interpersonal relationship. Communication Education, 49(3), 207219. https://doi.org/10.1080/036345 20009379209

Goodenow, C. (1993). Classroom belonging among early adolescent students: Relationships to motivation and achievement. Journal of Early Adolescence, 13(1), 113-126.

Guglielmino, L. M. (1977). Development of the self-directed learning readiness scale. Doctoral dissertation. University of Georgia.

Gündüz, G. F., \& Selfi, K. (2016). Developing a "self-directed learning implementation skills scale for primary school students": validity and reliability analysis. Agathos: $A n$ International Review of the Humanities and Social Sciences, 7(1).

Hare, W., \& McLaughlin, T. (1998). Four anxieties about open-mindedness: reassuring Peter Gardner. Journal of the Philosophy of Education, 32(2), 283-292. https://doi.org/10.1111/14679752.00093

Hinkin, T. R. (1995). A review of scale development practices in the study of organizations. Journal of Management, 21(5), 967-988. https://doi.org/10. 1177/014920639502100509

Huang, M. B. (2008). Factors influencing selfdirected learning readiness among Taiwanese nursing students. Thesis. The Queensland University of Technology. Retrieved from https:// eprints.qut.edu.au/20709/1/Meihui_Huang_Thesis.pdf 
Hughes, J. N. (2012). Teacher-student relationships and school adjustment: progress and remaining challenges. Attachment \& Human Development, 14(3), 319-327. https://doi.org/ 10.1080/14616734.2012.672288

Istiyani, D. (2009). Kesadaran dan selfdirected learning sebagai model pembelajaran alternatif dalam era neoliberalisme. Forum Tarbiyah, 7(2), 131-142.

Kan'an, A., \& Osman, K. (2015). The Relationship between self-directed learning skills and science achievement among Qatari students. Creative Education, 06(08), 790-797. https:// doi.org/10.4236/ce.2015.68082

Knowles, M. S. (1975). Self-directed learning: a guide for learners and teachers. Chicago: Follett Publishing Company.

Koca, F. (2016). Motivation to learn and teacher-student relationship. Journal of International Education and Leadership, 6(2), 1-20.

Krathwohl, D. R. (2002). A revision of Bloom's taxonomy: an overview. Theory Into Practice, 41(4), 212-218.

Likert, R. (1932). A technique for the measurement of attitudes. Archives of Psychology, 140, 5-55.

Lindsey, N. S., \& Rice, M. L. (2015). Interpersonal skills and education in traditional and online classroom environments. Journal of Interactive Online Learning, 13(3), 126-136.

Malan, S. B., Ndlovu, M., \& Engelbrecht, P. (2014). Introducing problem-based learning (PBL) into a foundation programme to develop self-directed learning skills. South African Journal of Education, 34(1), 1-16. https://doi. org/10.15700/201412120928

Norton, R. W., \& Pettegrew, L. S. (1977). Communicator style as an effect determinant of attraction. Communication Research, 4(3), 257-282. https://doi.org/10.1177/0093650277 00400302

Ryan, A. M., Pintrich, P. R., \& Midgley, C. (2001). Avoiding seeking help in the classroom: who and why? Educational Psychology Review, 13(2), 93-144. https:/ /doi.org/10.1023/A:1009013420053

Scott, C. L. (2015). The Futures of Learning 2: what kind of learning for the $21 \mathrm{st}$ century. Retrieved from http:// unesdoc.unesco.org/images/0024/00 2429/242996e.pdf

Seifert, T. (1993). Learning strategies in the classroom. Retrieved from https:// www.mun.ca/educ/faculty/mwatch/ vol2/seifert.html

Shen, W., Chen, H., \& Hu, Y. (2014). The validity and reliability of the selfdirected learning instrument (SDLI) in mainland Chinese nursing students. BMC Medical Education, 14(1), 108. https://doi.org/10.1186/1472-692014-108

Taqipour, M., Abbasi, E., Naeimi, A., Ganguly, S., \& Miandashti, N. Z. (2016). An investigation of selfdirected learning skills among the Iranian agricultural students (case of agricultural college, Tarbiat Modares University). Journal of Agricultural Science and Technology, 18(1), 15-26. Retrieved from http://mcej.modares.ac.ir/ browse.php?a_id $=6847 \&$ sid $=23 \&$ slc lang=en

Teven, J. J., \& McCroskey, J. C. (1997). The relationship of perceived teacher caring with student learning and teacher evaluation. Communication Education, 46(1), 1-9. https://doi.org/ 10.1080/03634529709379069

Wanzer, M. B., \& Frymier, A. B. (1999). The relationship between student perceptions of instructor humor and students' reports of learning. Communication Education, 48(1), 48-62. https://doi.org/10.1080/0363452990 9379152 
Warren, A. R. (2010). Impact of teaching students to use evaluation strategies. Physical Review Special Topics-Physics Education Research, 6(2), 1-12.

Williams, B., \& Brown, T. (2013). A confirmatory factor analysis of the Self-Directed Learning Readiness Scale. Nursing \& Health Sciences, 15(4), 430-436. https://doi.org/10.1111/ nhs.12046

Williamson, S. N. (2007). Development of a self-rating scale of self-directed learning. Nurse Researcher, 14(2), 66-83. https://doi.org/10.7748/nr2007.01.1 4.2.66.c6022
Yasa, P. (2014). Model belajar pemecahan masalah berbasis konteks untuk pengembangan kompetensi generik siswa kelas X SMA Negeri 3 Singaraja. In Seminar Nasional FMIPA UNDIKSHA IV Tabun 2014. Universitas Pendidikan Ganesha.

Ziyaeemehr, A., \& Kumar, V. (2014). The relationship between instructor humor orientation and students' report on second language learning. International Journal of Instruction, 7(1), 91-105. Retrieved from https://eric.ed.gov/ ?id=EJ1085255 